\title{
Phytotoxic, Cytotoxic and Insecticidal Activities of Chrysophthalmum dichotomum Boiss. and Heldr.
}

\author{
Fatma Ayaz ${ }^{1}$, Nurgün Küçükboyacı², Barış Bani ${ }^{3}$, Bilge Şener ${ }^{2}$, Muhammad lqbal Choudhary $^{4}$ \\ 1'Department of Pharmacognosy, Faculty of Pharmacy, Selcuk University, Konya, TURKEY. \\ ${ }^{2}$ Department of Pharmacognosy, Faculty of Pharmacy, Gazi University, Ankara, TURKEY. \\ ${ }^{3}$ Department of Biology, Faculty of Arts and Science, Kastamonu University, Kastamonu, TURKEY. \\ ${ }^{4}$ International Center for Chemical Sciences, University of Karachi, Karachi, PAKISTAN.
}

\begin{abstract}
Background: Chrysophthalmum dichotomum Boiss. and Heldr. (Asteraceae) is an endemic herbaceous plant to Southern part of Turkey. Aim: To investigate in vitro phytotoxic, cytotoxic and insecticidal activities of $C$. dichotomum. Methods: The $\mathrm{MeOH}$ extract of C. dichotomum was fractionated through subsequent solvent extractions in increasing polarity with $n$-hexane, chloroform and $n$-butanol. The $\mathrm{MeOH}$ extract and its fractions were evaluated for their biological acitivities using in vitro screening bioassays such as cytotoxicity on brine shrimps, phytotoxicity against Lemna minor and insecticidal activity against Rhyzopertha dominica and Tribolium castaneum. Results: The $n$-hexane and chloroform fractions showed significant phytotoxic activity $1100 \%$ growth inhibition) at $1000 \mu \mathrm{g} / \mathrm{ml}$ against $L$. minor. The brine shrimp lethality test revealed that the chloroform and remaining water fractions of $C$. dichotomum have moderate and positive lethality with $\mathrm{LD}_{50}$ values of 169.48 and $46.26 \mu \mathrm{g} / \mathrm{mL}$, respectively. In addition, the chloroform and $n$-butanol fractions had low and moderate insecticidal activity with 20 and $40 \%$ of mortality against Tribolium castaneum, respectively. Conclusion: This study demonstrates that $C$. dichotomum consists of bioactive constituents responsible for phytotoxicity, cytotoxicity on brine shrimps and insecticidal activity.
\end{abstract}

Key words: Chrysophthalmum dichotomum, Asteraceae, Phytotoxicity against Lemna minor, Cytotoxicity on brine shrimps, Insecticidal activity.

\section{INTRODUCTION}

The genus Chrysophthalmum Schultz Bip. (Asteraceae, tribus: Inulaeae) and consists of four species all over the world. In Turkey, the genus is represented by three species, namely C. montanum (DC.) Boiss., C. dichotomum Boiss. and Heldr. and C. gueneri Aytac and Anderb. C. dichotomum is an endemic herbaceous plant that grows in wooded or shrubby valley beds in the district of Antalya, Turkey. ${ }^{1}$ Up to date, no phytochemical and biological data has been reported on the plant. In our previous study, we firstly evaluated the cytotoxicity of $C$. dichotomum against selected cancer cell lines by Sulforhodamine B (SRB) assay. ${ }^{2}$

As a part of our continuing researches on the genus Chrysophthalmum, we recently evaluated the crude methanol extract and its fractions of $C$. montanum for their in vitro phytotoxic, cytotoxic and insecticidal activities. In that study, the crude extract, $n$-hexane and chloroform fractions have positive lethality on brine shrimp as well as $n$-hexane and chloroform fractions had significant phytotoxicity (100\% of growth inhibition) at $1000 \mu \mathrm{g} / \mathrm{mL}^{3}{ }^{3}$ In other our previous study, we found that chloroform extract of C. montanum and its isolated sesquiterpene lactones have significant cytotoxic activities on different cancer cell lines using SRB assay. ${ }^{4}$ Family Asteraceae is characterized by structurally diverse sesquiterpenes and, therefore it has been extensively studied in point of cytotoxic and anticancer activities. Sesquiterpenes have also been reported to use as toxic or insect-feeding deterrent..$^{5-6}$
Submission Date: 20-10-2017; Revision Date: 05-12-2017; Accepted Date: 17-05-2018

DOI: 10.5530/ijper.52.4s.105 Correspondence:

Prof. Nurgün Küçükboyacı, Department of

Pharmacognosy, Faculty of Pharmacy, Gazi University, 06330 Ankara, TURKEY.

E-mail: nurgun@gazi.edu.tr

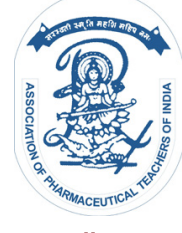

www.ijper.org 
Our ongoing researches on the genus Chrysophthalmum, we now aimed to investigate in vitro phytotoxic, cytotoxic and insecticidal activities of C. dichotomum.

\section{MATERIALS AND METHODS}

\section{Plant material}

Chrysophthalmum. dichotomum were collected from damp places in opening of Pinus nigra forest around Tinaztepe cave, in Konya in August, 2014. The plant was identified by one of our authors Barıs Bani $\mathrm{PhD}$, (Kastamonu University). Voucher specimen (F. Ayaz 46) was deposited at Herbarium of Gazi University (GAZI), Ankara, Turkey.

\section{Preparation of extracts}

The air-dried whole plants of $C$. dichotomum (150 g) were extracted four times $(4 \times 1500 \mathrm{~mL})$ with $80 \%$ methanol at $25^{\circ} \mathrm{C}$ by stirring for 2 days. Following filtration, the combined methanol extracts were evaporated in vacuo at $40^{\circ} \mathrm{C}$ to dryness. The concentrated $\mathrm{MeOH}$ extract $(25.8 \mathrm{~g}$ for $\mathrm{CD})$ were further fractionated by successive solvent extractions with $n$-hexane $(11 \times 200 \mathrm{~mL})$, chloroform $(8 \times 200 \mathrm{~mL})$ and $n$-butanol saturated with $\mathrm{H}_{2} \mathrm{O}(7 \times 200 \mathrm{~mL})$ in a separatory funnel. Each extract and remaining water phase $\left(\mathrm{R}-\mathrm{H}_{2} \mathrm{O}\right)$ after solvent extractions were evaporated to dryness under reduced pressure to yield " $n$-Hexane fraction" (1.1 g CDH), " $\mathrm{CHCl}_{3}$ fraction" (2.6 $\mathrm{g}$ for $\mathrm{CDC})$, “ $n$-BuOH fraction" (7.9 $\mathrm{g}$ for $\mathrm{CDB}$ ) and " $\mathrm{R}-\mathrm{H}_{2} \mathrm{O}$ fraction" (11.6 g CDR), respectively.

\section{Phytochemical analysis}

The $\mathrm{CHCl}_{3}$ extract of $C$. gueneri $(1 \mathrm{mg} / \mathrm{mL})$ was applied to silica gel plate. After developing with the mixture of chloroform: acetone (80:20) as mobile phases, TLC plate was evaluated under UV light at 254 and $366 \mathrm{~nm}$ for the determination of fluorescent compounds. Anisaldehyde reagent was sprayed on the plates to visualize the separated compounds and then plates were heated for $5 \mathrm{~min}$ at $100^{\circ} \mathrm{C}$. Sesquiterpenes appeared with pink and purple coloration.

\section{Phytotoxicity against Lemna minor}

The Lemna minor L. phytotoxicity assay was performed for the extracts of $C$. dichotomum by adopting the protocol as described by Atta-ur-Rahman. ${ }^{7}$ The medium was prepared by mixing various constituents in $1000 \mathrm{~mL}$ distilled water and $\mathrm{pH}$ was adjusted 6.0-7.0 by adding $\mathrm{KOH}$ pellets. The extracts $(30.0 \mathrm{mg})$ were dissolved in $1.5 \mathrm{~mL}$ of methanol (stock solution). The stock solutions of the extracts were diluted to get final concentrations as 10,100 and $1000 \mu \mathrm{g} / \mathrm{mL}$. The solvent was allowed to evaporate overnight under sterile condition. To each flask was then added $20 \mathrm{~mL}$ medium and 10 plants, each one containing a rosette of two fronds of $L$. minor. Other flasks were supplemented with medium and reference plant growth inhibitor (Paraquate) as negative and positive controls, respectively. All flasks were kept in growth cabinet for 7 days. The number of fronds per flasks was counted and recorded at the end of the incubation period. The growth regulation as a percentage $(\%)$ was determined using the formula given below:

Growth regulation $(\%)=\frac{100-\text { Number of fronds in test samples }}{\text { Number of fronds in negative control }} \times 100$

The activity criteria indicate that the growth regulation $(\%)$ of $0-39 \%$ for low activity, $40-59 \%$ for moderate activity, $60-69 \%$ for good activity and $>70 \%$ for significant activity were detected.

\section{Cytotoxicity on brine shrimps}

Brine shrimp (Artemia saline Leach) eggs (50 mg) were sprinkled in a hatching tank (a rectangular dish $22 \times 32 \mathrm{~cm}$ ) half-filled with filtered brine solution. The extracts $(20 \mathrm{mg})$ were dissolved in $2 \mathrm{~mL}$ of methanol (stock solution). The concentrations of 10,100 and $1000 \mu \mathrm{g} / \mathrm{mL}$ of each extracts from stock solutions were prepared in three vials and the solvent was evaporated by keeping over night. 2 days of hatching later, 30 shrimps were added in each vial with the volume adjusted to $5 \mathrm{ml}$ using sea water. The vials were incubated at $25-27^{\circ} \mathrm{C}$ for $24 \mathrm{~h}$ under illumination. Other vials were supplemented with solvent, and reference cytotoxic drug (Etoposide: $7.4625 \mu \mathrm{g} / \mathrm{ml}$ ) which served as - ve and + ve controls, respectively. The number of brine shrimps that survived was counted in each vial and $\mathrm{LD}_{50}$ values with $95 \%$ confidence intervals were determined using Finney computer software. ${ }^{8-9}$

\section{Insecticidal activity}

The extracts of $C$. dichotomum were tested against Rhyzopertha dominica and Tribolium castaneum using impregnated filter paper method. ${ }^{10}$ The extracts $(200 \mathrm{mg})$ were dissolved in $3 \mathrm{~mL}$ of methanol (stock solution). The extracts were applied to filter paper $\left(1019.10 \mu \mathrm{g} / \mathrm{cm}^{2}\right)$ of appropriate size $(9 \mathrm{~cm}$ or $90 \mathrm{~mm}$ ) on petri plates using micropipette. The plates were left for $24 \mathrm{~h}$ to evaporate the solvent. The next day, 10 insects of each species were placed in each plate [test and permethrin (239.5 $\mu \mathrm{g} / \mathrm{cm}^{2}$ ) was used as + ve control; methanol was used as - ve control] using a clean brush. The plates were incubated at $27^{\circ} \mathrm{C}$ for $24 \mathrm{~h}$ with $50 \%$ relative humidity in the growth chamber. For the calculation, the number of survivals of each species was counted and mortality (\%) was determined using the following formula: 


$$
\text { Mortality }(\%)=\frac{100-\text { Number of insects alive in test samples }}{\text { Number of insects alive in control }} \times 100
$$

\section{RESULTS}

In our study, we investigated the methanol extract and its fractions of $C$. dichotomum for their in vitro phytotoxic, cytotoxic and insecticidal activities. The phytotoxicity of the tested samples on $L$. minor was observed to have dose dependent activity, because low activity was detected in the chloroform and $n$-butanol fractions with 19.0 and $10.6 \%$ inhibition at $100 \mu \mathrm{g} / \mathrm{mL}$, respectively, as well as in remaining water fraction with $37.5 \%$ inhibition at $1000 \mu \mathrm{g} / \mathrm{mL}$. Moderate phytotoxic activity was found in the $n$-butanol fraction $(42.6 \%$ inhibition) at $1000 \mu \mathrm{g} / \mathrm{mL}$. Significant phytotoxic activity was shown in the $n$-hexane and chloroform fractions of the plant; $100.0 \%$ inhibition for each fraction at 1000 $\mu \mathrm{g} / \mathrm{mL}$ (Table 1).

The cytotoxic properties of the extract and fractions of $C$. dichotomum were investigated at a concentration of 10,100 and $1000 \mu \mathrm{g} / \mathrm{mL}$, using etoposide as a standard. The chloroform and remaining water fractions had moderate and positive lethality with $\mathrm{LD}_{50}$ values of 169.48 and $46.26 \mu \mathrm{g} / \mathrm{mL}$ against the brine shrimps, respectively (Table 2).

The extract and fractions of $C$. dichotomum were also screened for their insecticidal effects against Rhyzopertha dominica and Tribolium castaneum using permethrin as a standard drug. The chloroform and $n$-butanol fractions had low and moderate insecticidal activities with 20 and $40 \%$ of mortality against Tribolium castaneum, respectively. There was no insecticidal effect on all tested samples against Rhyzopertha dominica (Table 3).

\section{DISCUSSION}

To date, a number of plant extracts prepared in different solvents was screened to determine the preliminary

\begin{tabular}{|c|c|c|c|}
\hline \multirow{2}{*}{ Sample } & \multicolumn{3}{|c|}{$\%$ Growth inhibition } \\
\hline & $10 \mu \mathrm{g} / \mathrm{mL}$ & $100 \mu \mathrm{g} / \mathrm{mL}$ & $1000 \mu \mathrm{g} / \mathrm{mL}$ \\
\hline CD & 0 & 0 & 0 \\
\hline CDH & 0 & 0 & 100.0 \\
\hline CDC & 0 & 19.0 & 100.0 \\
\hline CDB & 0 & 10.6 & 42.6 \\
\hline CDR & 0 & 0 & 37.5 \\
\hline
\end{tabular}

Standard drug: Paraquate $(0.015 \mu \mathrm{g} / \mathrm{mL})$

\begin{tabular}{|c|c|c|c|c|}
\hline \multirow[b]{2}{*}{ Sample } & \multicolumn{3}{|c|}{ No of survivals from 30 shrimps } & \multirow{2}{*}{$\begin{array}{c}\mathrm{LD}_{50} \\
(\mu \mathrm{g} / \mathrm{mL})\end{array}$} \\
\hline & $\begin{array}{c}10 \\
\mu \mathrm{g} / \mathrm{mL}\end{array}$ & $\begin{array}{c}100 \\
\mu \mathrm{g} / \mathrm{mL}\end{array}$ & $\begin{array}{c}1000 \mu \mathrm{g} / \\
\mathrm{mL}\end{array}$ & \\
\hline CD & 23 & 22 & 17 & 5900.97 \\
\hline CDH & 28 & 25 & 21 & - \\
\hline CDC & 24 & 25 & 03 & 169.48 \\
\hline CDB & 18 & 16 & 15 & 771.45 \\
\hline CDR & 16 & 15 & 12 & 46.26 \\
\hline
\end{tabular}

Standard drug: Etoposide $\left(L D_{50}=7.46 \mu \mathrm{g} / \mathrm{mL}\right)$

Table 3: Insecticidal activities of the extract and fractions of $\boldsymbol{C}$. dichotomum.

\begin{tabular}{|c|c|c|}
\hline \multirow{2}{*}{ Sample } & \multicolumn{2}{|c|}{$\%$ Mortality } \\
\cline { 2 - 3 } & Tribolium castaneum & Rhyzopertha dominica \\
\hline CD & 0 & 0 \\
\hline CDH & 0 & 0 \\
\hline CDC & 20 & 0 \\
\hline CDB & 40 & 0 \\
\hline CDR & 0 & 0 \\
\hline
\end{tabular}

Reference insecticide: Permethrin $\left(239.5 \mu \mathrm{g} / \mathrm{cm}^{2}\right)$

cytotoxic activity on brine shrimp larvae. Brine shrimp lethality assay is a preliminary method for the assessment of cytotoxic compounds which could show a significant correlation with their anticancer potentials. ${ }^{11-13}$ In addition, to develop natural herbicides and insecticides that are safe and user friendly for the environment is important for screening in terms of phytotoxic and insecticidal activities of plants. ${ }^{14}$

According to our results, the chloroform fraction of C. dichotomum was found as a promising sample due to having cytotoxicity on brine shrimps. In our previous study, the chloroform fraction of $C$. dichotomum exhibited cytotoxicity on MCF-7, MDA-MB-231, LNCaP, PC-3 (lung) and HT-29 cancer cell lines using SRB assay with \% viability values $22.99,21.08,24.27,16.02$ and 28.00, respectively. ${ }^{2}$ Our preliminary phytochemical analysis of the bioactive chloroform fraction by TLC depicted that sesquiterpenes were detected as principal components.

\section{CONCLUSION}

The present study firstly showed that the potential of C. dichotomum on biological activities such as cytotoxicity on brine shrimps, phytotoxic and insecticidal effects in vitro. Further investigations are continuing on the isola- 
tion and characterization for the responsible bioactive constituents from $C$. dichotomum.

\section{ACKNOWLEDGEMENT}

This study was supported by TUBİTAK-2214/A and ICCBS-HEJ. TUBİTAK-2214/A, TUBİTAK-2211/A and ICCBS-HEJ.

\section{CONFLICT OF INTEREST}

The authors declare no conflict of interest..

\section{ABBREVIATIONS USED}

SRB: Sulforhodamine B; CD: The Concentrated MeOH extract; CDH: n-Hexane fraction; CDC: $\mathrm{CHCl} 3$ Fraction; CDB: n-BuOH fraction; CDR: R-H2O Fraction.

\section{REFERENCES}

1. Grierson AJC. Chrysophthalmum Schultz Bip. In: Flora of Turkey and the East Aegean Islands, Davis, PH, ed., Vol 5, Edinburgh: Edinburgh University Press. 1975;5:52-3.

2. Ayaz F, Kucukboyaci N, Sarimahmut M, Bani B, Duman H, Ulukaya E, et al. "Cytotoxic Activity of the Genus Chrysophthalmum Schultz Bip. From Turkey Against Various Human Cancer Cell Lines", 3rd EACR-Sponsored Anticancer Agent Development Congress. 2015:42. 2015, İmir, Turkey.
3. Ayaz F, Küçükboyacı N, Duman H, Şener B, Choudhary MI. Cytotoxic, Phytotoxic and Insecticidal Activities of Chrysophthalmum montanum (DC.) Boiss Turk. J Pharm Sci. 2017;14:290-3.

4. Ayaz F, Kucukboyaci N, Goren N, Calis I, Aydinlik S, Ulukaya E, et al. "Bioassay-Guided Isolation and Cytotoxic Effects of Extract and Chemical Constituents of Chrysophthalmum montanum (DC.) Boiss. Of Turkish Origin", Turk. J Biochem. 2016;41(S4):46.

5. Fraga BM. Natural sesquiterpenoids. Nat Prod Rep. 2004;21:669-93.

6. Rodriguez E, Towers GH, Mitchell JC. Biological activities of sesquiterpene lactones. Phytochemistry. 1976;15(11):1573-80.

7. Atta-ur-Rahman. Studies in Natural Product Chemistry. The Netherlands: Elsevier Science Publishers BV. 1991;9:383-409.

8. Meyer BN, Ferrigni NR, Putnam JE, Jacobsen LB, Nicholas PE, McLaughin JL. Brine Shrimp: A convenient general bioassay for active plant constituents. Planta Med. 1982;45(5):31-4.

9. Finny DJ. Probit Analysis. 3rd ed. Cambridge: Cambridge University Press.1971:333.

10. Atta-ur-Rahman, Choudhary MI, William JT. Bioassay techniques for drug development. The Netherlands: Harward Academic Publisher. 2001:67-8.

11. Ullah R, Ibrar M, Shah S, Hameed I. Phytotoxic, cytotoxic and insecticidal activities of Calendula arvensis L. E3 J Biotechnol Pharm. Res. 2012;3(6):104-11.

12. Khuda F, Iqbal Z, Khan A, Nasir F, Muhammad N, Khan JA, et al. Metal analysis, phytotoxic, insecticidal and cytotoxic activities of selected medicinal plants of Khyber Pakhtunkhwa. Pak J Pharm. Sci. 2012;25(1):51-8.

13. Uddin G, Rehman TU, Arfan M, Liaqat W, Mohammad G, Choudhary MI. Phytochemical analysis, antifungal and phytotoxic activity of seeds of medicinal plant Indigofera heterantha Wall. Middle-East J Sci Res. 2011;8:603-5.

14. Saeed M, Muhammad N, Khan H, Khan SA. Analysis of toxic heavy metals in branded Pakistani Herbal Products. J Chem Soc Pak. 2010;32(4):471-5.

\section{PICTORIAL ABSTRACT}

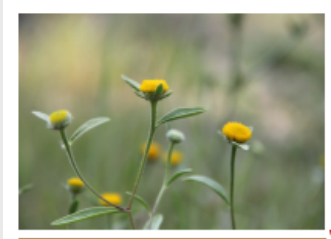

Chrysophthalmum dichotomum Boiss. and Heldr.

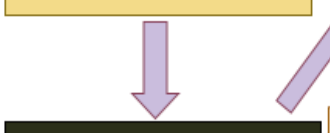

80\% Methanol Extract

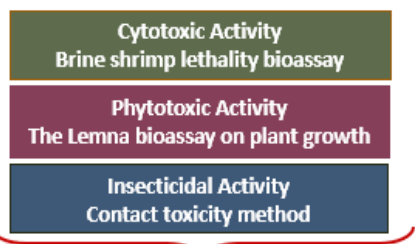

Contact toxicity method
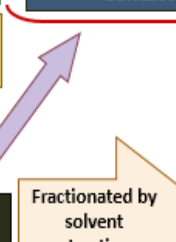
extraction
$n$-Hexane fraction

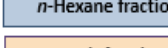

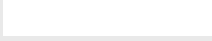
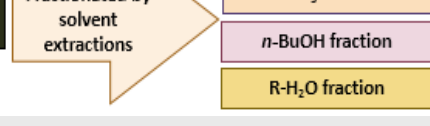

\section{SUMMARY}

- In the present study was investigated on C. dichotomum on biological activities such as cytotoxicity

- brine shrimps, cytotoxicity and insecticidal effects in vitro.

- The chloroform fraction of $C$. dichotomum showedmoderate cytotoxicity on brine shrimps.

- Significant phytotoxic activity was shown in the $n$-hexane and chloroform fractions of the plant.

\section{About Authors}

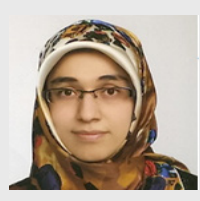

Dr. Ayaz: Has been graduated from Hacettepe Univ., Fac. of Pharmacy in 2011 as the Second Degree. She has completed her Ph.D. (Pharmacognosy) with "Pharmacognosic Researches on Chrysophthalmum Schultz Bip. Species Growing in Turkey" in 2017. In 2018, she became an Assist. Professor in Selcuk Univ. Fac. of Pharmacy. She has been working in the Department of Pharmacognosy, Faculty of Pharmacy, Selcuk University, Konya, Turkey. 


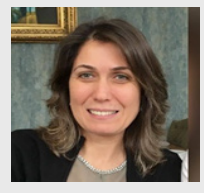

Prof. Küçükboyacı: Received her PhD degree in Pharmacognosy in 1999 from Gazi University, Ankara, Turkey. She is currently the Head of the Department of Phytopharmacy, Faculty of Pharmacy, Gazi University. Her research interests include the development of natural compounds from medicinal plants and the evaluation of their biological activities as well as phytomedicines. She has been working in the Department of Pharmacognosy, Faculty of Pharmacy, Gazi University, Ankara, Turkey.

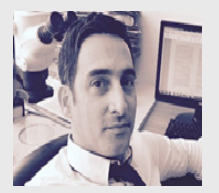

Dr. Baris Bani: Is working in the Department of Biology from Kastamonu University, Kastamonu, Turkey. His research area is plant taxonomy.

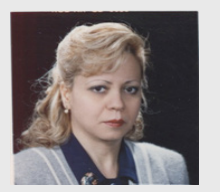

Prof. Sener: Has been graduated from Ankara Univ., Fac. of Pharmacy in 1974 as the First Degree. She has completed her Ph.D. (Pharmacognosy) awarded by TUBITAK in 1977. In 1981, she became an Assoc. Professor. She was involved within the process of establishing Dept. of Pharmacognosy, Fac. of Pharmacy, Gazi University in 1982. She achieved some researches at the Dept. of Chemistry, The Pennsylvania State University (USA) $1986-1988$ as Visiting scientist awarded by NSF. She became a full Professor in 1988. Prof. Sener also involved several administrative works at Gazi University; as Director at the Dept. of Pharmacognosy, Chair of the Division, Co-Director at the Inst. of Health Sciences and Dean at the Faculty of Pharmacy. Her main research field is development of bioactive compounds, evaluation of Phytomedicines and Nutraceuticals. She has won 21 awards. The degree of "Adjunct Professor" was given to her by University of Karachi, Pakistan. She has completed 48 projects from NATO, NSF, IUPAC, Soctrates-Grundtvig, TUBITAK and Universirty Research Funds. 11 books, 88 chapters and 662 research articles alongwith 68 conferences and 315 plenary, invited lectures for her credit. She has supervised 5 Ph.D., 13 M.Sc. at Gazi University as well as co-supervised 17 Ph.D. thesis at the University of Karachi. She is a member for 14 scientific societies.

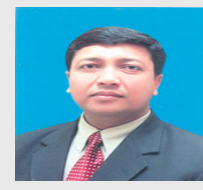

Dr. Muhammad Iqbal Choudhary Is Director and Professor of Bioorganic and Natural Product Chemistry at the International Center for Chemical and Biological Sciences (H. E. J. Research Institute of Chemistry and Dr. Panjwani Center for Molecular Medicine and Drug Research). Prof. Choudhary has, since 1990, been among the world leaders in the field of natural product chemistry, and has made pioneering contributions in the discovery of novel natural products. He has discovered many potent anti-epileptic and anti-leishmanial compounds from indigenous medicinal plants that are under clinical trials. His contributions to reverse bacterial resistance to antibiotics represent seminal contributions in this important field. He leads the developing world's finest research center of natural product chemistry (HEJ Research Institute of Chemistry) since 2002, and has trained hundreds of young researchers, especially women, from across the Afro-Asian region in natural product chemistry. He has established several research centers in Pakistan, and helped to setup research units in Africa, and South and Central Asia. His scientific, and capacity building contributions have been recognized by prestigious national and international awards and honors, and fellowships of several academies of science. Prof. Choudhary has 1016 publications (Citations 13,000, $\mathrm{h}$ index 44 ) in the fields of organic and bioorganic chemistry, along with 60 international patents (46 US Patents), 59 books and 40 chapters in books, published by major U.S. and European presses. On the basis of his researches, 73 students have been awarded Ph.D. degrees in various areas of natural product and bioorganic chemistry.

Cite this article: Ayaz F, Küçükboyaci N, Bani B, Sener B, Choudhary MI. Phytotoxic, Cytotoxic and Insecticidal Activities of Chrysophthalmum dichotomum Boiss. and Heldr. Indian J of Pharmaceutical Education and Research. 2018;529(4 Suppl 2):s252-s256. 